Jolanta Ciak* Bożena Kołosowska**

\title{
SYSTEM EMERYTALNY I JEGO ZMIANY W POLSCE W KONTEKŚCIE DEFICYTU BUDŻETOWEGO ORAZ DŁUGU PUBLICZNEGO W LATACH 1999-2014
}

\section{Wprowadzenie}

Powstające kryzysy gospodarcze wymuszają odpowiednie zmiany w zachowaniach rządów i przedsiębiorstw. Niezwykle podatne na takie oddziaływanie są systemy emerytalne, w których szuka się rozwiązań pozwalających zmniejszyć powstającą w nich nierównowagę czy też - co jest groźniejsze - deficyt w budżecie państwa. Takie działania dostrzega się także w Polsce, gdzie od 2010 r. szuka się rozwiązań mających na celu sfinansowanie bieżących potrzeb budżetowych państwa. Artykuł ma na celu ukazanie zmian zachodzących w polskim powszechnym systemie emerytalnym i ich wpływu na finanse publiczne, w tym na budżet państwa. Autorzy dostrzegają, iż proponowane przez rząd zmiany można by określić jako wybór pomiędzy odpowiedzialnością za dzisiaj a odpowiedzialnością za przyszłość. Można stwierdzić, że skutki dzisiejszych zmian w systemie emerytalnym przesuwane są na dalsze pokolenia, a źródła ich finansowania będą uzależnione od prowadzonej w przyszłości polityki gospodarczej, w tym finansowej.

\section{Nowy system emerytalny w Polsce po 1999 roku - wprowadzenie do tematyki}

Najważniejszym elementem procesu tworzenia nowego systemu emerytalnego była reforma z 1999 r., której wprowadzenie uzasadniano':

\footnotetext{
* Wyższa Szkoła Bankowa w Toruniu, Wydział Finansów i Zarządzania.

** Uniwersytet Mikołaja Kopernika w Toruniu, Wydział Nauk Ekonomicznych i Zarządzania.

1 Bezpieczeństwo dzięki różnorodności. Reforma systemu emerytalnego w Polsce, Biuro Pełnomocnika Rządu ds. Reformy Zabezpieczenia Społecznego, Warszawa 1997.
} 
- groźbą katastrofy finansów ubezpieczeń społecznych i finansów publicznych jako skutkiem mających nastąpić po $2010 \mathrm{r}$. zmian demograficznych,

- wysokim udziałem budżetu w finansowaniu świadczeń emerytalno-rentowych,

- złym stanem finansów ubezpieczeń społecznych,

- wysokim obciążeniem pracodawców kosztami pracy,

- niskim poziomem świadczeń.

Już na samym początku wdrażania reformy wielu ekonomistów wskazywało na istnienie wielu niewiadomych. J. Czekaj twierdził, iż budzą obawę nie w pełni rozeznane skutki finansowe reformy w odniesieniu do budżetu, a także niepokoi niepewność co do rzeczywistej zdolności towarzystw emerytalnych do utrzymywania i pomnażania wartości środków pochodzących ze składek². Precyzyjne określenie skutków finansowych wprowadzenia systemu w życie okazało się niezwykle trudne ze względu na dużą liczbę zmiennych, takich jak: działania racjonalizujące istniejący system i ich skuteczność, tempo wzrostu PKB, tempo wzrostu wydajności pracy, wpływ reformy na wzrost gospodarczy oraz absorpcja szarej strefy.

Zmiany, jakie nastąpiły w obowiązującym systemie ubezpieczeń społecznych od 1 stycznia 1999 r., spowodowały wzrost wydatków ponoszonych przez budżet państwa. Wpłynęło na to kilka przyczyn ${ }^{3}$ :

- przekazanie części składki na ubezpieczenia społeczne do otwartych funduszy emerytalnych (20\% wartości opłacanej składki),

- obniżenie składki na ubezpieczenia społeczne dla osób o najwyższych zarobkach, ze względu na to, iż składki opłaca się tylko od wynagrodzenia miesięcznego wynoszącego do 2,5 przeciętnego wynagrodzenia,

- możliwość przekazania przez pracodawcę części składki (do 7\%) do pracowniczego programu emerytalnego (czego skutki finansowe są omówione w dalszej części opracowania),

- $\quad$ wprowadzenie obowiązku opłacania składki na ubezpieczenia społeczne z budżetu państwa (np. za osoby na urlopach wychowawczych, za żołnierzy służby zasadniczej),

- wzrost kosztów funkcjonowania ZUS, m.in. w wyniku wprowadzenia nowego systemu informatycznego, naprawiania błędów w systemie informatycznym i innych przyczyn.

Ze względu na utratę części składki, która zasila OFE, należy zapewnić płynność FUS-u poprzez zwiększenie dotacji z budżetu państwa. Sytuację dodatkowo pogarsza

2 J. Czekaj, Skala i formy prywatyzacyjnego wsparcia reformy emerytalno-rentowej, w: Reforma systemu emerytalnego $w$ Polsce, Rada Strategii Społeczno-Gospodarczej przy Radzie Ministrów, raport nr 24, Warszawa 1997, s. 67.

3 B. Kołosowska, Skutki finansowe reformy systemu emerytalnego $w$ Polsce, Wydawnictwo UMK, Toruń 2004, s. 60 . 
fakt, że na istniejący deficyt związany z ubezpieczeniami społecznymi nałożył się dodatkowy deficyt w związku z prowadzoną reformą systemu. Od 1999 r. znacząco wzrastają kwoty z budżetu państwa zasilające Fundusz Ubezpieczeń Społecznych. W 1998 r. kwota dotacji dla FUS-u wynosiła około 6,8 mld PLN, rok później była to już wielkość 9,6 mld, by wzrosnąć w 2001 r. do poziomu przekraczającym 21 mld PLN. Dotacja celowa i uzupełniająca do FUS-u w 2002 r. wynosiła już 27 mld PLN. Są to kwoty uzupełniające środki FUS-u z tytułu przekazania części środków do OFE, przekroczenia 30-krotności podstawy naliczania składki na obowiązkowe ubezpieczenia społeczne oraz uzupełnienia środków na wypłatę świadczeń.

$\mathrm{Z}$ biegiem lat następowały kolejne istotne działania konstruujące polski system emerytalny, takie jak

- przywrócenie systemu zaopatrzeniowego dla wszystkich żołnierzy zawodowych i funkcjonariuszy tzw. służb mundurowych, a tym samym wyłączenie ich z systemu powszechnego w 2003 r.,

- uchwalenie znowelizowanej ustawy o pracowniczych programach emerytalnych (PPE),

- wprowadzenie indywidualnych kont emerytalnych (IKE) w 2004 r.,

- wprowadzenie uprzywilejowanych emerytur górniczych pod naciskiem związków zawodowych w 2005 r.,

- wprowadzenie zmian w zakresie funkcjonowania II filaru w 2011 r.,

- podniesienie i zrównanie powszechnego wieku emerytalnego w 2012 r.,

- modyfikacje w funkcjonowaniu OFE oraz możliwość przeniesienia części środków z OFE do ZUS w 2014 r.

\section{Zmiany w pracowniczym systemie emerytalnym po 2011 roku}

Głównym powodem wprowadzenia zmian w 2011 r. był coroczny deficyt w Funduszu Ubezpieczeń Społecznych, który w istotny sposób przyczynił się do obciążenia budżetu państwa. Tworzący się na przestrzeni lat deficyt FUS-u wynikał z różnicy pomiędzy wartością wypłacanych emerytur a sumą zgromadzonych składek emerytalnych. Taka nierównowaga była następstwem tego, iż wypłacane emerytury

4 T. Jedynak, Charakterystyka systemu emerytalnego w ramach powszechnego ubezpieczenia społecznego, w: Systemy ubezpieczeń społecznych, red. W. Sułkowska, Wydawnictwo Uniwersytetu Ekonomicznego w Krakowie, Kraków 2014, s. 48. 
z FUS-u w przeważającej mierze stanowiły świadczenia należne ubezpieczonym w ramach,,starego" systemu emerytalnego, zgodnie ze schematem systemu repartycyjnego finansowane ze składek osób należących do "nowego” systemu. Powstanie takiej różnicy było nieuchronnym następstwem wprowadzonych w 1999 r. zmian. Od 1999 r. osoby pracujące musiały ponosić ciężar finansowania emerytur w ramach „starego", w pełni repartycyjnego systemu emerytalnego, jak i budować część kapitałową "nowego" systemu. Po reformie emerytalnej z 1999 r. jedynie 12,22\% podstawy wymiaru składki na ubezpieczenie emerytalne było przeznaczane na wypłatę bieżących emerytur, a pozostałe 7,3\% docierało do części kapitałowej systemu, która miała stanowić podstawę do wypłaty części emerytury w przyszłości.

$\mathrm{Na}$ mocy znowelizowanej ustawy z 2011 r. zmieniono obowiązujący dotychczas podział składki emerytalnej w taki sposób, że ograniczono część składki przekazywanej do OFE, a uzyskane w ten sposób środki przekierowano do dyspozycji ZUS-u z przeznaczeniem na pokrycie deficytu FUS-u (czyli wypłatę bieżących emerytur $)^{5}$. Oddane do dyspozycji środki są ewidencjonowane na nowo powstałych tzw. subkontach administrowanych przez ZUS. Z kolei środki w ramach II filaru (7,3\% podstawy wymiaru składki na ubezpieczenie emerytalne) dzielone były pomiędzy indywidualne konto ubezpieczonego w OFE, na którym odnotowano składkę w wysokości 3,5\% podstawy wymiaru, oraz subkonto kapitałowe w ZUS, na które przypadała składka w wymiarze $3,8 \%$ podstawy wymiaru. Wskazany podział składki przekazywanej do OFE (3,5\%) był sprecyzowany jako poziom końcowy w $2017 \mathrm{r}$.

Tabela 1. Kształt polskiego systemu emerytalnego po zmianach w 2011 r.

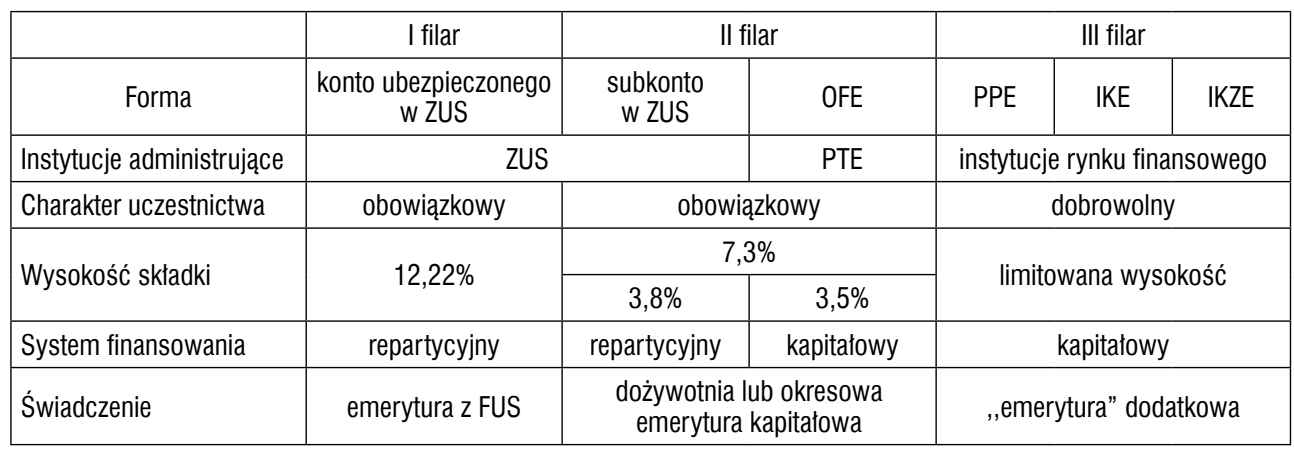

Źródło: T. Jedynak, Charakterystyka systemu emerytalnego w ramach powszechnego ubezpieczenia społecznego, w: Systemy ubezpieczeń społecznych, red. W. Sułkowska Wydawnictwo Uniwersytetu Ekonomicznego w Krakowie, Kraków 2014, s. 54.

5 Ustawa z dnia 25 marca 2011 r. o zmianie niektórych ustaw związanych $\mathrm{z}$ funkcjonowaniem systemu ubezpieczeń społecznych, Dz. U. 2011, nr 75, poz. 398, z późn. zm. 
W 2012 r. część składki przekazywanej do OFE wynosiła 2,3\%, a w 2013 r. 2,8\%. W 2014 r. miała wynosić 3,1\%, a w 2015-2016 3,3\%. Jednak wprowadzenie kolejnych zmian w systemie emerytalnym w 2014 r. sprawiło, że założenia na kolejne lata są nieaktualne ${ }^{6}$.

Następną zmianą w polskim systemie emerytalnym było pojawienie się w ramach dobrowolnej płaszczyzny III filaru indywidualnych kont zabezpieczenia emerytalnego (IKZE). Główną przyczyną wprowadzenia jeszcze jednego instrumentu dodatkowego oszczędzania na emeryturę było niskie zainteresowanie Polaków gromadzeniem środków na cele emerytalne poprzez IKE czy też PPE. W zestawieniu z niską prognozowaną stopą zastąpienia z części bazowej emerytury groziło to perspektywą wysoce niesatysfakcjonujących dochodów po zaprzestaniu aktywności zawodowej

\section{Kolejne zmiany $w$ architekturze polskiego systemu emerytalnego}

Kolejnym istotnym etapem budowy polskiego systemu emerytalnego w $2012 \mathrm{r}$. było podjęcie decyzji o podniesieniu wieku emerytalnego do 67 lat oraz zrównania go dla kobiet i mężczyzn. Do 2012 r. podstawowy wiek emerytalny wynosił 60 lat dla kobiet i 65 lat dla mężczyzn, a więc kształtował się na takim samym poziomie, jak wiek emerytalny w „starym” systemie. Ustawa z dnia 11 maja 2012 r. przewiduje, że modyfikacje te będą wprowadzane stopniowo od 1 stycznia 2013 r., wydłużając wiek emerytalny co kwartał o 1 miesiąc ${ }^{8}$. Dzięki takim założeniom wiek 67 lat osiągną mężczyźni przechodzący na emeryturę po 2020 r., a kobiety po 2040 r. Występują jednak pewne odstępstwa od tej reguły, takie jak m.in. wcześniejsze emerytury dla osób urodzonych przed 1 stycznia 1969 r., które nie przystąpiły do OFE; emerytury pomostowe, emerytury mundurowe, górnicy itp.

W 2014 r. ponownie ze względu na zły stan finansów publicznych oraz niewydajność w funkcjonowaniu II filaru wprowadzono kolejną korektę w systemie emerytalnym. Bezpośrednim objawem złego stanu finansów publicznych było realne zagrożenie przekroczenia tzw. drugiego progu ostrożnościowego (sytuacja, gdy dług publiczny przekracza 55\% PKB). Coroczny deficyt w FUS stanowił jedynie część

\footnotetext{
6 www.mpips.gov.pl/.../20131010_Uzasadnienie\%20do\%20projektu\%20ustawy.pdf, dostęp 18.02.2015.

7 Ustawa z dnia 20 kwietnia 2004 r. o indywidualnych kontach emerytalnych, Dz. U. nr 116, poz. 1205, z późn zm., tj. Dz. U. 2014, poz. 1147.

8 Ustawa z dnia 11 maja 2012 r. o zmianie ustawy o emeryturach i rentach z Funduszu Ubezpieczeń Społecznych oraz niektórych innych ustaw, Dz. U. nr 0, poz. 637.
} 
obciążeń budżetu, które doprowadziły do trudnej sytuacji finansów publicznych. Zarzuty związane $z$ brakiem efektywności II filaru dotyczyły przede wszystkim funkcjonowania otwartych funduszy emerytalnych. Podnoszone kwestie odnosiły się m.in. do racjonalności nabywania przez OFE obligacji Skarbu Państwa. (Finansowano w ten sposób potrzeby pożyczkowe państwa, które były związane przede wszystkim $\mathrm{z}$ koniecznością pokrycia deficytu w FUS. Tym samym poprzez kupowane przez OFE obligacje skarbowe następował generujący dodatkowe koszty transfer środków w ramach systemu emerytalnego). Ponadto problem ten obejmował również obowiązkowość przekazywania części składek do OFE, efektywność mechanizmu konkurencji pomiędzy poszczególnymi OFE, a także limity inwestycji w poszczególne kategorie aktywów nałożonych na OFE. Stan niepewności wywoływały dodatkowo kwestie związane ze stosunkowo wysokimi opłatami pobieranymi przez OFE9.

W ostateczności, na mocy ustawy z 6 grudnia 2013 r. o zmianie niektórych ustaw w związku z określeniem zasad wypłaty emerytur ze środków zgromadzonych w otwartych funduszach emerytalnych (Dz. U., poz. 1717), wdrożono następujące korekty w systemie emerytalnym ${ }^{10}$ :

- przeniesienie posiadanych przez OFE obligacji Skarbu Państwa do ZUS, a także ich umorzenie, $\mathrm{z}$ jednoczesnym zapisem wynikających z nich uprawnień ubezpieczonych na subkoncie kapitałowym w ZUS,

- sprecyzowanie wymiaru składki przekazywanej do OFE na poziomie $2,92 \%$ podstawy wymiaru,

- umożliwienie ubezpieczonym dokonania wyboru w zakresie uczestnictwa w OFE,

- zniesienie mechanizmu minimalnej stopy zwrotu oraz zmiana limitów inwestycyjnych OFE,

- modyfikacje w systemie opłat pobieranych przez OFE.

W okresie od 1 kwietnia do 31 lipca 2014 r. członkowie OFE podejmowali decyzję, czy składka w wysokości 2,92\% podstawy wymiaru nadal ma być przekazywana do OFE ${ }^{11}$. Decyzja dotyczy tego, czy ta część składki nadal ma być przekazywana do OFE, czy też ma zostać zewidencjonowana na subkoncie w ZUS, wraz z przekazywaną już na to subkonto składką w wysokości 4,38\%.

Decyzję o dalszym przekazywaniu składek do OFE można podjąć wyłącznie w okresie tzw. „okienek transferowych”. Pierwsze z nich rozpoczęło się 1 kwietnia 2014 r. i trwało do 31 lipca 2014 r.

\footnotetext{
9 T. Jedynak, op.cit., s. 56.

10 Ustawa z dnia 6 grudnia 2013 r. o zmianie niektórych ustaw w związku z określeniem zasad wypłaty emerytur ze środków zgromadzonych w otwartych funduszach emerytalnych, Dz. U., poz. 1717.

${ }^{11}$ www.mpips.gov.pl/.../skladka-na-ubezpieczenie-emerytalne/, dostęp 19.03.2015.
} 
Decyzja, jaka zostanie podjęta przez członka OFE nie jest ostateczna, będzie ją można zmienić w okresie od kwietnia do lipca w 2016 r., a następnie co cztery lata. W okienkach transferowych można będzie zmienić poprzednią decyzję o sposobie przekazywania składek, do OFE, czy na subkonto lub odwrotnie. Oznacza to wprowadzenie dobrowolności w zakresie przekazywania przyszłych składek do OFE.

Ustalono podział składki emerytalnej w wypadku podjęcia decyzji o przekazywaniu składki wyłącznie na subkonto w ZUS: 19,52\%, konto w ZUS, 12,22\%, subkonto w ZUS 7,3\%. Podział składki emerytalnej w wypadku podjęcia decyzji o dalszym przekazywaniu składki na rachunek w OFE jest następujący: 19,52\%, konto w ZUS, $12,22 \%$, subkonto w ZUS, 4,38\%, rachunek w OFE 2,92\%.

Składka wpłacana do otwartego funduszu emerytalnego i na subkonto w ZUS pochodzi w całości z części opłacanej przez ubezpieczonego.

Składki wpłacone do ZUS podlegają corocznej waloryzacji, tj pomnożeniu przez wskaźnik waloryzacji; środki przekazywane do otwartych funduszy emerytalnych pomnażane są poprzez inwestycje na rynkach finansowych. Waloryzacja środków zewidencjonowanych na kontach emerytalnych w ZUS zależy od inflacji i wzrostu płac w gospodarce. Składki ewidencjonowane na subkoncie podlegają waloryzacji wskaźnikiem równym średniorocznej dynamice wartości PKB za okres ostatnich pięciu lat.

Na ubezpieczenie emerytalne odprowadzana jest składka w wysokości 19,52\% podstawy wymiaru składki, czyli wynagrodzenia brutto.

Od 1 lutego 2014 r. do końca czerwca 2014 r. składka na ubezpieczenie emerytalne w wysokości ${ }^{12}$ :

- $12,22 \%$ ewidencjonowana jest na koncie w ZUS,

- 4,38\% ewidencjonowana jest na subkoncie w ZUS,

- $2,92 \%$ odprowadzana jest na rachunek w otwartym funduszu emerytalnym.

Od lipca 2014 r., w zależności od dokonanego przez ubezpieczonego wyboru, część składki na ubezpieczenie emerytalne wynosząca 2,92\% będzie odprowadzana przez Zakład Ubezpieczeń Społecznych do wybranego przez ubezpieczonego otwartego funduszu emerytalnego (OFE) lub ewidencjonowana na subkoncie ubezpieczonego w ZUS (łącznie 7,3\%).

Do 30 czerwca 2014 r. podział składki i przekazanie jej części do OFE były obowiązkowe dla ubezpieczonych urodzonych po 31 grudnia 1968 r., co oznaczało, że byli oni obowiązani do zawarcia umowy z otwartym funduszem emerytalnym. W wypadku niezawarcia umowy w ustawowym terminie, ZUS wskazywał otwarty fundusz emerytalny poprzez losowanie. Ostatnie losowanie odbyło się 31 stycznia 2014 r.

12 http://emerytura.gov.pl/system-emerytalny/skladka-emerytalna/, dostęp 19.02.2015. 
Ubezpieczeni urodzeni po 31 grudnia 1948 r., a przed 1 stycznia 1969 r., z wyjątkiem osób pobierających emeryturę, mogli na swój wniosek przystąpić, w drodze zawarcia umowy, do wybranego otwartego funduszu emerytalnego.

W wypadku ubezpieczonych, którzy nie przystąpili do otwartego funduszu emerytalnego, cała składka na ubezpieczenie emerytalne (19,52\%) przekazywana jest do FUS i ewidencjonowana na indywidualnym koncie ubezpieczonego prowadzonym przez ZUS.

Obecny kształt powszechnego systemu emerytalnego po uwzględnieniu wszelkich zmian i korekt przedstawiono w tabeli 2.

Tabela 2. Kształt polskiego systemu emerytalnego po zmianach w 2014 r.

\begin{tabular}{|c|c|c|c|c|c|c|c|}
\hline & \multicolumn{2}{|r|}{ I filar } & \multicolumn{2}{|c|}{ II filar } & \multicolumn{3}{|c|}{ III filar } \\
\hline Forma & $\begin{array}{l}\text { konto ubezpieczonego } \\
\text { w ZUS }\end{array}$ & subkonto w ZUS & \multicolumn{2}{|c|}{ OFE } & PPE & IKE & IKZE \\
\hline $\begin{array}{l}\text { Instytucje } \\
\text { administrujące }\end{array}$ & \multicolumn{2}{|r|}{ ZUS } & \multicolumn{2}{|c|}{ PTE } & \multicolumn{3}{|c|}{$\begin{array}{l}\text { instytucje rynku } \\
\text { finansowego }\end{array}$} \\
\hline $\begin{array}{l}\text { Charakter } \\
\text { uczestnictwa }\end{array}$ & obowiązkowy & $\begin{array}{l}\text { obowiązkowy z możliwością } \\
\text { przeniesienia środków z OFE } \\
\text { w wypadku rezygnacji }\end{array}$ & \multicolumn{2}{|c|}{$\begin{array}{l}\text { możliwość } \\
\text { rezygnacji }\end{array}$} & \multicolumn{3}{|c|}{ dobrowolny } \\
\hline \multirow{4}{*}{ Wysokość składki } & \multirow{4}{*}{$12,22 \%$} & & \multicolumn{2}{|c|}{$7,30 \%$} & \multirow{4}{*}{\multicolumn{3}{|c|}{$\begin{array}{l}\text { limitowana } \\
\text { wysokość }\end{array}$}} \\
\hline & & & $7,30 \%$ & $0,00 \%$ & & & \\
\hline & & & \multicolumn{2}{|c|}{$\begin{array}{c}\text { lub (wybór } \\
\text { ubezpieczonego) }\end{array}$} & & & \\
\hline & & & $4,38 \%$ & $2,92 \%$ & & & \\
\hline System finansowania & repartycyjny & repartycyjny & \multicolumn{2}{|c|}{ kapitałowy } & \multicolumn{3}{|c|}{ kapitałowy } \\
\hline Świadczenie & \multicolumn{4}{|c|}{ emerytura z FUS z uwzględnieniem środków zgromadzonych w OFE } & \multicolumn{3}{|c|}{$\begin{array}{l}\text {,emerytura" } \\
\text { dodatkowa }\end{array}$} \\
\hline
\end{tabular}

Źródło: www.mpips.gov.pl/.../20131010_Uzasadnienie\%20do\%20projektu\%20ustawy.pdf, dostęp 18.02.2015.

\section{Wpływ zmian w systemie emerytalnym na finanse publiczne w latach 2010-2014}

Ukształtowany w ciągu ostatnich kilkunastu lat system emerytalny, funkcjonujący w ramach sektora finansów publicznych, wpłynął w znaczący sposób na sytuację finansową tego sektora. Dodatkowo ostatnie zmiany w zakresie OFE z 2014 r. nie pozostały bez znaczenia dla całego sektora rządowego. Warto zatem przeanalizować ten wpływ na niektóre kwestie, a mianowicie na deficyt budżetu państwa oraz dług publiczny i jego relacje do PKB. Analizę rozpoczniemy od ogólnej sytuacji 
w Funduszu Ubezpieczeń Społecznych oraz w budżecie państwa. W tabeli 3 przedstawiono wybrane wskaźniki związane z funkcjonowaniem FUS w latach 2010-2014.

Tabela 3. Sytuacja w FUS w latach 2010-2014 (w mld PLN)

\begin{tabular}{|l|r|r|r|r|r|}
\hline \multicolumn{1}{|c|}{ Wyszczególnienie } & 2010 & 2011 & 2012 & 2013 & $2014^{*}$ \\
\hline Przychody FUS & 119,5 & 122,3 & 132,5 & 136,4 & $157,9^{*}$ \\
\hline Wydatki FUS & 130,4 & 139,0 & 151,5 & 168,3 & 191,8 \\
\hline Deficyt FUS & 10,9 & 16,7 & 19,0 & 31,9 & 33,9 \\
\hline Dotacja z budżetu państwa do FUS & 38,1 & 37,5 & 39,5 & 37,1 & 30,4 \\
\hline Środki z FRD & 7,5 & 4,0 & 2,9 & 2,5 & 2,5 \\
\hline Refundacja składki do OFE & 22,3 & 15,4 & 8,2 & 10,9 & 8,2 \\
\hline Pożyczka dla FUS & 5,5 & 5,0 & 3,0 & 12,0 & 6,8 \\
\hline Stan pożyczek do FUS tącznie & 10,87 & 15,87 & 18,87 & 30,87 & 37,3 \\
\hline
\end{tabular}

* Wartość prognozowana.

Źródło: Opracowanie własne na podstawie Sprawozdania z wykonania budżetu państwa za lata 2010-2013; ustawy budżetowe za lata 2010-2014; Egzekucja należności z tytułu składek na ubezpieczenie społeczne. Informacja o wynikach kontroli, NIK, Warszawa 24.07.2014.

Analiza tabeli 3 skłania do wyciągnięcia następujących wniosków:

- wpływy do FUS są niewystarczające na pokrycie bieżących wydatków. Od 2010 r. widoczny jest rosnący deficyt w budżecie FUS i to pomimo znaczących środków przekazywanych rokrocznie w formie dotacji budżetowej. Środki te stanowily średnio $26 \%$ ogółu przychodów FUS,

- przychody FUS są uzupełniane środkami finansowymi przekazywanymi z Funduszu Rezerwy Demograficznej. W badanym okresie były one zróżnicowane i wahały się od 2,5-7,5 mld PLN,

- permanentny niedobór FUS dodatkowo wspierany jest pożyczką pochodzącą z rozchodów budżetowych, co oznacza przepływ środków poza budżetem państwa. Środki te nie powiększają wielkości deficytu budżetu państwa. Kwota zobowiązań FUS tylko z tego tytułu miała wynieść na koniec 2014 r. 37,3 mld zł,

- w związku z koniecznością przekazywania przez ZUS części składki emerytalnej do OFE następował systematyczny ubytek składek na ubezpieczenia społeczne w FUS. Ubytek ten był refundowany przez budżet państwa w postaci transferu do FUS środków w wysokości składek przekazywanych do OFE. Ich wysokość była zróżnicowana i w latach 2010-2014 wahała się między 8,2 w 2012 r. i 2014 r. do 22,3 mld PLN w $2010 \mathrm{r}$.

Warto podkreślić, iż wspomniane działania niekorzystnie wpływają na finanse publiczne, w szczególności na budżet państwa. Mają też znaczenie dla ogólnego wzrostu potrzeb pożyczkowych całego sektora finansów publicznych. Permanentna, 
dodatkowa pomoc państwa dla FUS skutkowała i skutkuje głęboką nierównowagą budżetu państwa, która wymaga dodatkowych źródeł finansowania owego deficytu ${ }^{13}$. Kwestie kształtowania się dochodów, wydatków i salda budżetu państwa zostały przedstawione w tabeli 4 .

Tabela 4. Dochody, wydatki oraz saldo budżetu państwa w Polsce w latach 2010-2014 (w mld PLN)

\begin{tabular}{|l|r|r|r|r|r|}
\hline \multicolumn{1}{|c|}{ Wyszczególnienie } & 2010 & 2011 & 2012 & 2013 & 2014 \\
\hline Dochody & 250,3 & 277,6 & 287,6 & 279,2 & 277,8 \\
\hline Wydatki & 294,9 & 302,7 & 318,0 & 321,4 & 325,4 \\
\hline Deficyt & 44,6 & 25,1 & 30,4 & 42,2 & 47,4 \\
\hline
\end{tabular}

Źródło: Opracowanie własne na podstawie Sprawozdania Ministerstwa Finansów z wykonania budżetu państwa za lata 2010-2013; dla roku 2014 Ustawa budżetowa na 2014 r.

W badanym okresie, tj. w latach 2010-2014, w budżecie państwa widoczne były znaczne rozbieżności pomiędzy zrealizowanymi dochodami i wydatkami. Dochody wykazywały tendencję zmienną, z kolei wydatki przez cały ten okres wzrastały. Efektem tego był wysoki deficyt budżetowy. Deficyt ten miał największy udział w deficycie całego sektora finansów publicznych. Był on w znaczący sposób potęgowany potrzebami płynącymi z sektora ubezpieczeń społecznych. W 2013 r. deficyt budżetowy i deficyt sektora ubezpieczeń społecznych wynosił 74,1 mld PLN. W 2014 r. deficyt sektora finansów publicznych bez sektora ubezpieczeń społecznych został zaplanowany na 82 mld PLN.

Jak wspomniano we wcześniejszych rozważaniach, ubytek dochodów pochodzących ze składek na ubezpieczenia społeczne powoduje wzrost deficytu budżetu państwa. Dodatkowo, wpływ na wzrost deficytu budżetowego mają koszty obsługi długu publicznego emitowanego na potrzeby OFE. Jak wskazuje się w literaturze przedmiotu, bez konieczności finansowania dodatkowych potrzeb z tytułu OFE (na sfinansowanie wcześniejszych składek do OFE) relacja długu do PKB byłaby znacząco niższa i nawet w kryzysowych latach tj. 2009-2012 utrzymywałaby się na poziomie poniżej $40 \% \mathrm{PKB}^{14}$, a jego wartość nie przekroczyłaby w 2014 kwoty 1 bln PLN ${ }^{15}$.

Kwestie wielkości długu publicznego w Polsce w relacji do PKB z OFE i bez OFE obrazuje tabela 5 .

${ }^{13}$ Szerzej na temat źródeł finansowania deficytu budżetu państwa w Polsce J. Ciak, Źródła finansowania deficytu budżetu państwa w Polsce, CeDeWu, Warszawa 2012.

${ }_{14}$ Zob. Przeglad funkcjonowania systemu emerytalnego. Bezpieczeństwo dzięki zrównoważeniu, MPiPS, MF, Warszawa, czerwiec 2013, s. 34.

${ }_{15}$ Zob. Na liczniku długu publicznego wybije 1000000000 000 zł, www.bankier.pl, dostęp 10.03.2015. 
Tabela 5. Relacja długu sektora publicznego i długu sektora bez OFE w latach 2010-2013 do PKB (w \%)

\begin{tabular}{|l|c|c|c|c|}
\hline \multicolumn{1}{|c|}{ Wyszczególnienie } & 2010 & 2011 & 2012 & 2013 \\
\hline Dług sektora publicznego do PKB & 54,8 & 56,2 & 55,6 & 57,1 \\
\hline Dług sektora publicznego do PKB bez OFE & 38,4 & 39,2 & 38,1 & 38,1 \\
\hline
\end{tabular}

Źródło: Dług publiczny. Raporty roczne za lata 2010-2013, Ministerstwo Finansów

\section{Podsumowanie}

Obowiązujący od 1999 r. w Polsce system emerytalny ze względu na swoją konstrukcję staje się bardzo podatny na sytuacje kryzysowe pojawiające się w zmieniającym otoczeniu. W celu zmniejszenia powstających deficytów, szuka się rozwiązań mających na celu sfinansowanie bieżących potrzeb budżetowych państwa.

Przeprowadzona analiza wskazuje na niekorzystną sytuację zarówno w samym budżecie państwa, jak i w Funduszu Ubezpieczeń Społecznych, który nie ma możliwości samodzielnie sprostać wymogom nowego systemu ubezpieczeń społecznych. Ponadto sytuacja demograficzna w Polsce też będzie miała negatywny wpływ na finanse FUS-u. Już obecnie bieżące składki na ubezpieczenie społeczne są niewystarczające na pokrycie wydatków związanych między innymi z wypłatą rent i emerytur. Wzrost liczby świadczeniobiorców, przy jednoczesnym zmniejszaniu się liczby osób płacących składki na ubezpieczenie społeczne, będzie sprzyjał pogłębianiu się nierównowagi w FUS. Zgodnie z informacjami zawartymi w publikacji pokontrolnej Najwyższej Izby Kontroli saldo ujemne FUS ma być w kolejnych latach coraz wyższe, odpowiednio w 2015 r. - 53,1 mld PLN, w 2020 r. - 56,4 mld PLN, z kolei w 2025 r. - 64,5 mld PLN ${ }^{16}$.

Oznacza to zatem, że przyszłe pokolenie będzie musiało ponieść negatywne skutki wprowadzenia systemu, w którym - w kilkudziesięcioletnim okresie przejściowym - płaci się podwójne koszty funkcjonowania systemu emerytalnego, finansowanie bieżących emerytur i ufundowanie kapitałowego filaru ubezpieczeń społecznych. W jakim stopniu dla kolejnych pokoleń koszt ten będzie miał formę wyższych podatków, mniejszych wydatków publicznych czy wyższego długu publicznego, zależeć będzie od prowadzonej w przyszłości polityki gospodarczej.

16 Zob. Egzekucja należności z tytułu składek na ubezpieczenia społeczne. Informacja o wynikach kontroli, NIK, Warszawa 24.07.2014, s. 7. 


\section{Bibliografia}

Bezpieczeństwo dzięki różnorodności. Reforma systemu emerytalnego w Polsce, Biuro Pełnomocnika Rządu ds. Reformy Zabezpieczenia Społecznego, Warszawa 1997.

Ciak J., Źródła finansowania deficytu budżetu państwa w Polsce, CeDeWu, Warszawa 2012.

Czekaj J., Skala i formy prywatyzacyjnego wsparcia reformy emerytalno-rentowej, Reforma systemu emerytalnego $w$ Polsce, Rada Strategii Społeczno-Gospodarczej przy Radzie Ministrów, Warszawa 1997, nr 24.

Egzekucja należności z tytułu składek na ubezpieczenie społeczne. Informacja o wynikach kontroli, NIK, Warszawa 24.07.2014.

Jedynak T., Charakterystyka systemu emerytalnego $w$ ramach powszechnego ubezpieczenia społecznego, Systemy ubezpieczeń społecznych, red. W. Sułkowska, Wydawnictwo Uniwersytetu Ekonomicznego, Kraków 2014.

Kołosowska B., Skutki finansowe reformy systemu emerytalnego w Polsce, Wydawnictwo UMK, Torun 2004.

Przeglą funkcjonowania systemu emerytalnego. Bezpieczeństwo dzięki zrównoważeniu, MPiPS, MF, Warszawa czerwiec 2013.

Ustawa z dnia 6 grudnia 2013 r. o zmianie niektórych ustaw w związku z określeniem zasad wypłaty emerytur ze środków zgromadzonych w otwartych funduszach emerytalnych, Dz. U., poz. 1717.

Ustawa z dnia 11 maja 2012 r. o zmianie ustawy o emeryturach i rentach z Funduszu Ubezpieczeń Społecznych oraz niektórych innych ustaw, Dz. U. nr 0, poz. 637.

Ustawa z dnia 20 kwietnia 2004 r. o indywidualnych kontach emerytalnych, Dz. U. nr 116, poz. 1205, z późn zm., tj. Dz. U. 2014, poz. 1147.

Na liczniku długu publicznego wybije $1000000000000 z$, http://emerytura.gov.pl/system-emerytalny/skladka-emerytalna/, dostęp 19.02.2015.

www.mpips.gov.pl/.../20131010_Uzasadnienie\%20do\%20projektu\%20ustawy.pdf, dostęp 18.02.2015.

www.mpips.gov.pl/.../skladka-na-ubezpieczenie-emerytalne/, dostęp 19.03.2015.

\section{The Pension System and its Changes in Poland in the Context of Budget Deficit and Public Debt in years 1999-2014}

Since January 1999 a new pension system based on the reformed Social Insurance Institution (ZUS) and open pension funds (OFE) has been in force. The reforms did not concern all the insured in ZUS uniformly, due to its scope and costs. The 
aim of the article is to present the changes in the Polish national pension system and their influence on the public finance including the state budget. The influence is considerable due to the long-lasting imbalance in the state budget and the accumulating public debt. The authors discern that the changes suggested by the government can be assessed as the choice between being responsible for present and being responsible for the future. Thus the effects of the current changes in the pension system are moved to the future generations and the sources of their financing, whether they are in the form of higher taxes, smaller public expenditure or higher public debt, will depend on the future economic policy including the financial policy.

Keywords: pension system, open pension funds, budget deficit and public debt

\section{Le système de retraite et ses modifications en Pologne dans le contexte du déficit budgétaire et de la dette publique dans les années 1999-2014}

Depuis janvier 1999, un nouveau système de retraite, basé sur l'Institut d'assurance sociale (ZUS) après la réforme et les Fonds de pension ouverts (OFE), est en vigueur. Les réformes n’ont pas concerné tous les assurés de façon uniforme, en raison de leur champ d'application et leurs coûts. Le but de l'article est de présenter les changements dans le système de retraite polonais et leur influence sur les finances publiques, y compris le budget de l'État. L'influence est considérable en raison du déséquilibre de longue durée dans le budget de l'État et de l'accumulation de la dette publique. Selon les auteurs les modifications proposées par le gouvernement peuvent être considérées comme le choix entre la responsabilité pour aujourd'hui et la responsabilité pour l'avenir. Ainsi, les effets des changements d'aujourd'hui dans le système de retraite auront une incidence sur les générations futures, et la source de leur financement - sous la forme d'une hausse des impôts, d'une baisse des dépenses publiques ou d'une dette publique élevée - dépendra de la future politique économique, y compris la politique financière.

Mots-clés: le système de retraite, les fonds de pension ouverts, le déficit budgétaire, la dette publique 


\section{Пенсионная система и ее изменения в Польше в контексте бюджетного дефицита и государственного долга в 1999-2014 гг.}

В январе 1999 г. вступила в силу новая пенсионная система, основанная на реформированном Управлению социального страхования (ZUS) и открытых пенсионных фондах (OFE). Из-за масштаба изменений и связанных с тем затрат, реформы не охватывают всех застрахованных в ZUS равномерно. Целью статьи является указать изменения в польской пенсионной системе и их влияние на государственные финансы, включая государственный бюджет. Это влияние значительное, что связано с длительным дисбалансом в государственном бюджете и накоплением государственного долга. Авторы подчеркивают, что изменения, предложенные правительством, можно расценивать как выбор между ответственностью за настоящее и ответственностью за будущее. Таким образом, эффекты текущих изменений в пенсионной системе адресированны будущим поколениям. Источники их финансирования, которые могут быть связаны с более высокими налогами, меньшими государственными расходами или более высоким государственным долгом, будут зависеть от будущей экономической политики, включая финансовую политику.

Ключевые слова: пенсионная система, открытые пенсионные фонды, дефицит бюджета и государственный долг 